S.H. CHOI*,**, B. ALI*,***, S.K. HYUN**, J.J. SIM*,**, W.J. CHOI*, W. JOO*,

J.H. LIM*, Y.J. LEE****, T.S. KIM*,***\#, K.T. PARK*\#

\title{
FABRICATION OF A SPHERICAL TITANIUM POWDER BY COMBINED COMBUSTION SYNTHESIS AND DC PLASMA TREATMENT
}

\begin{abstract}
Combustion synthesis is capable of producing many types of refractory and ceramic materials, as well as metals, with a relatively lower cost and shorter time frame than other solid state synthetic techniques. $\mathrm{TiO}_{2}$ with $\mathrm{Mg}$ as reductant were dry mixed and hand compacted into a $60 \mathrm{~mm}$ diameter mold and then combusted under an Ar atmosphere. Depending on the reaction parameters (Mg concentration $2 \leq \alpha \leq 4)$, the thermocouples registered temperatures between $1160^{\circ} \mathrm{C}$ and $1710^{\circ} \mathrm{C} .3 \mathrm{~mol}$ of $\mathrm{Mg}$ gave the optimum results with combustion temperature $\left(T_{c}\right)$ and combustion velocity $\left(U_{c}\right)$ values of $1372^{\circ} \mathrm{C}$ and $0.26 \mathrm{~cm} / \mathrm{s}$ respectively. Furthermore, this ratio also had the lowest oxygen concentration in this study $(0.8 \mathrm{wt} \%)$. After combustion, DC plasma treatment was carried out to spheroidize the Ti powder for use in $3 \mathrm{D}$ printing. The characterization of the final product was performed using X-ray diffraction, scanning electron microscopy, energy dispersive spectroscopy, and N/O analysis.

Keywords: Combustion synthesis, DC plasma treatment, Titanium powder, 3D printing process, Combustion parameters
\end{abstract}

\section{Introduction}

Titanium metal sees significant use in the aerospace, chemical processing, automotive and biomedical industries [1-2] due to its high strength to weight ratio, ductility, corrosion resistance and biocompatibility [3-4]. Recently, three-dimensional (3D) metal printing processes have been recognized as a flexible and rapid means of fabricating complex shapes such as implants and scaffolds, which are otherwise difficult to produce using conventional material processing techniques [5-9]. When Ti powder is used for $3 \mathrm{D}$ printing, it is best to use a spherical powder of approximately $100 \mu \mathrm{m}$ diameter, in addition to having good powder flow, a tap density $>65 \%$, and low oxide content [11].

Commercial production of titanium is typically carried out using the Kroll process, which reduces titanium chloride to titanium metal [10]. The process involves three steps as shown in Fig. 1. The first step involves a chlorination process in which titanium oxide ore is converted to its chloride form. The second stage is based on the magnesiothermic reduction of titanium chloride and production of a titanium metal sponge. Lastly, the titanium sponge is converted into a powder through various gas atomization powder production techniques such as plasma rotating atomization, electrode induction melting gas atomization, and plasma wire atomization [11].
Despite numerous advancements in the Kroll process, such as producing clean Ti metal with higher than $3 \mathrm{~N}$ purity and large-scale bulk materials ( $>1$ ton/batch), it still requires multiple phase transitions (oxide $\rightarrow$ halide $\rightarrow$ metal), $\mathrm{Cl}_{2}$ gas needed for preparing $\mathrm{TiCl}_{4}$, long operation times, and a particularly costly raw material in $\mathrm{Ti}$ [12-13]. In addition, Ti sponge is used as a raw material in atomization processes for producing $\mathrm{Ti}$ powders, which involves re-melting and applying high pressure gas jets to a Ti melt. Owing to this fact, many researchers have sought an alternative to the Kroll process, such as the Hunter, Fray-Farthing-Chen, and Ono-Suzuki processes [14-16].

Self-propagating high temperature synthesis (SHS) and simple combustion synthesis (CS) have been studied for the fabrication of Ti powder [17-18]. CS is a highly sophisticated and efficient powder production technique that has many advantages over other conventional processes, such as fast production rate, high energy efficiency, direct oxide reduction, simplified equipment and high purity in the final products (Fig. 1) [19].

In this study, the possibility of directly reducing $\mathrm{TiO}_{2}$ to $\mathrm{Ti}$ metal by $\mathrm{CS}$ is investigated. $\mathrm{TiO}_{2}$ is used as the raw material, while $\mathrm{Mg}$ metal is utilized as a reducing agent. The molar ratio of $\mathrm{Mg}$ is controlled as a process parameter of Ti powder preparation. After CS, DC plasma treatment is carried out to spheroidize the Ti powder into a raw material for $3 \mathrm{D}$ printing.

\footnotetext{
KOREA INSTITUTE FOR RARE METALS, KOREA INSTITUTE OF INDUSTRIAL TECHNOLOGY, ELEVENTH FLOOR, GET-PEARL TOWER, GAETBEOL-RO 12, YEONSU-GU, INCHEON, SOUTH KOREA

** DEPARTMENT OF ADVANCED MATERIALS ENGINEERING, IN-HA UNIVERSITY, IN-CHEON, SOUTH KOREA

*** DEPARTMENT OF RARE METALS ENGINEERING, UNIVERSITY OF SCIENCE AND TECHNOLOGY, DAE-JEON, SOUTH KOREA

**** DEPARTMENT OF ADVANCE MATERIAL ENGINEERING, CHUNGNAM NATIONAL UNIVERSITY, DAEJEON, SOUTH KOREA 


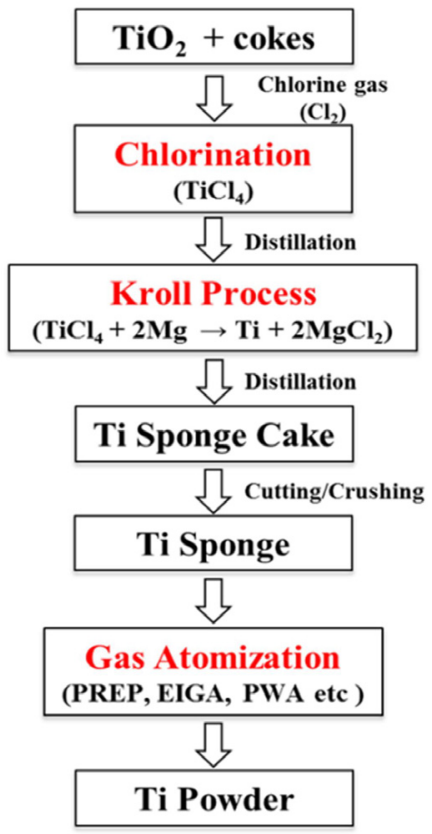

(a)

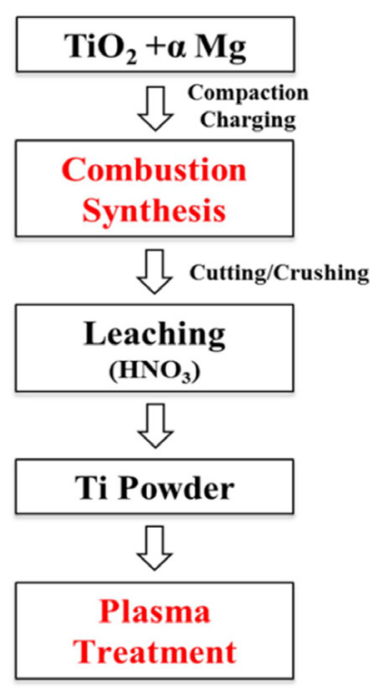

(b)
Fig. 1. Flow charts of (a) conventional Ti powder manufacturing and (b) the CS process

\section{Experimental}

\subsection{Preparations of Combustion Synthesis and Spheroidization}

Titanium dioxide powder $\left(\mathrm{TiO}_{2}, 99.99 \%\right.$, particle size $2 \mu \mathrm{m}$, Kojundo Chemical Laboratory Co., Ltd, Japan) and magnesium powder $(\mathrm{Mg},>98.5 \%$, particle size $<74 \mu \mathrm{m}$, DaeJung Chemicals $\&$ Metals Co., Ltd, S. Korea) were used as raw materials. These materials in molar ratios of $1: 2$ to $1: 4\left(\mathrm{TiO}_{2}: \mathrm{Mg}\right)$ were dry mixed for 30-60 min using a mortar, and then hand compacted in a cylindrical mold $60 \mathrm{~mm}$ in diameter and $120 \mathrm{~mm}$ high. This mixture was then placed in a steel autoclave with under $\operatorname{Ar}$ gas $(2.5 \mathrm{MPa})$ and ignited with a resistively heated Nichrome $(\mathrm{Ni}-\mathrm{Cr})$ wire.

During combustion, the synthesis follows the chemical pathway shown in Eq. 1. The combustion temperature $\left(T_{c}\right)$ was measured by inserting W-Re Type-C thermocouples (WRe $26 \% / \mathrm{W}-\operatorname{Re} 5 \%$ ) in the middle and bottom of the sample. These thermocouples were coated with ceramic material in order to prevent any reaction with the mixture powder. Time, temperature and pressure profiles were continuously recorded at a time interval of $0.1 \mathrm{~s}$. From these data, the combustion wave propagation velocity $\left(U_{c}\right)$ was calculated as $U_{c}=x / t$ ( $x$ : distance between thermocouples, t: time interval between temperature profiles).

The obtained burnt sample was loosely sintered. The surface layer was partially removed and the sample was ground into a powder. In order to remove the $\mathrm{Mg}$ and $\mathrm{MgO}$ byproducts predicted by Eq. 2, this powder was treated with dilute nitric acid $\left(\mathrm{HNO}_{3}\right.$, DukSan PureChemicals Co., Ltd, 64-66\%) by stirring the mixture for $1.5 \mathrm{~h}$ and subsequently rinsing it with distilled water. The mixture was then dried at $80^{\circ} \mathrm{C}$ for $24 \mathrm{~h}$ to obtain the final Ti powder. Spheroidization and size control of the $\mathrm{Ti}$ powder was carried out using DC plasma treatment, using the parameters shown in Table 1.

TABLE 1

Experimental conditions of DC plasma treatment

\begin{tabular}{|c|c|c|c|c|c|c|c|}
\hline \hline $\begin{array}{c}\text { Classi- } \\
\text { fication }\end{array}$ & $\begin{array}{c}\text { Power } \\
\text { (kW) }\end{array}$ & $\begin{array}{c}\text { Cur- } \\
\text { rent } \\
\text { (A) }\end{array}$ & $\begin{array}{c}\text { Vol- } \\
\text { tage } \\
\text { (V) }\end{array}$ & $\begin{array}{c}\text { Discharge } \\
\text { Gas } \\
\text { (L/min) }\end{array}$ & $\begin{array}{c}\text { Pres- } \\
\text { sure } \\
\text { (torr) }\end{array}$ & $\begin{array}{c}\text { Feed- } \\
\text { ing } \\
\text { rate }\end{array}$ & $\begin{array}{c}\text { Carrier } \\
\text { gas } \\
\text { (L/min) }\end{array}$ \\
\hline $\begin{array}{c}\text { Para- } \\
\text { meter }\end{array}$ & 9.0 & 300 & 30 & $\mathrm{Ar}, 15$ & 760 & $\begin{array}{c}1.0 \mathrm{~g} / \\
\text { min }\end{array}$ & $\mathrm{Ar}, 3$ \\
\hline
\end{tabular}

$$
\begin{gathered}
\mathrm{TiO}_{2}+\alpha \mathrm{Mg} \rightarrow \mathrm{Ti}+2 \mathrm{MgO}+(\alpha-2) \mathrm{Mg} \\
\mathrm{Ti}+\mathrm{MgO}(\mathrm{Mg})+2 \mathrm{HNO}_{3}+\mathrm{nH}_{2} \mathrm{O} \rightarrow \mathrm{Ti}+ \\
+\mathrm{Mg}\left(\mathrm{NO}_{3}\right)_{2}+(\mathrm{n}+1) \mathrm{H}_{2} \mathrm{O}
\end{gathered}
$$

\subsection{Analysis of combustion products}

Thermodynamic calculations (equilibrium concentration of the reaction phases (mole) and adiabatic combustion temperature $T_{a d}\left({ }^{\circ} \mathrm{C}\right)$ ) were performed using the FactSage 7.0 software, equilibrium module (CRCT-Thermfact Inc., Canada \& GTT-Technologies, Germany). Adiabatic temperature $\left(T_{a d}\right)$ was calculated using Eq. 3.

$$
\begin{aligned}
-\Delta H_{f}^{0}\left(T_{0}\right)= & \int_{T_{0}}^{T_{m}} C_{P s}(P) d T+\Delta H_{m}+ \\
& +\int_{T_{m}}^{T_{a d}} C_{P l}(P) d T, \text { if } T_{a d}>T_{m}
\end{aligned}
$$

Phase identification of the combusted powder was performed using X-ray diffraction (XRD, Rigaku RINT-TTR, Japan). The powder morphology was analyzed by field emission scanning electron microscopy (FE-SEM, JEOL JSM-7100F, Japan) and the particle size distribution was calculated using dry particle size analysis (PSA, Beckman Coulter LS I3 320, USA). The oxygen content of powder was estimated by N/O analysis (Eltra GmbH ONH 2000, Germany). Activation energy of the $\mathrm{TiO}_{2}+\alpha \mathrm{Mg}$ (where $\alpha=$ molar concentration of $\mathrm{Mg}$ ) system was calculated from an Arrhenius plot drawn by utilizing $U_{c}$ and $T_{c}$ values. An experimental flow diagram of this study is presented in Fig. 2.

\section{Results and discussion}

CS utilizes an exothermic heat of reaction for synthesis. Therefore, the first step in designing a CS reaction is to choose a combination of reactive elements that reacts in an exothermic manner. Generally, a combination of a metal oxide and a reducing element such as $\mathrm{Mg}$ or $\mathrm{Al}$ is used, where exothermic heat is 


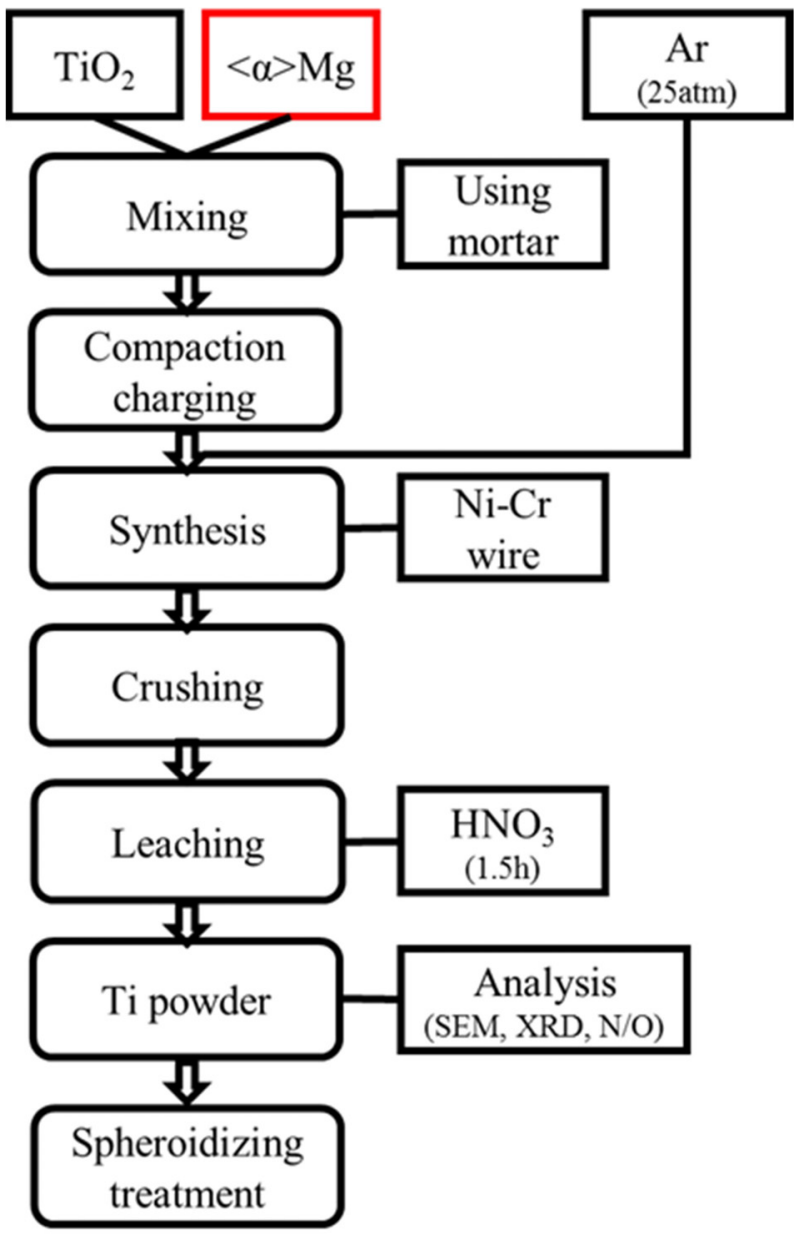

Fig. 2. Experimental Process flow diagram

generated during the reduction of the metal oxide to pure metal. The general form of this process is shown in Eq. 4 .

$$
\begin{aligned}
\mathrm{MeO}(\text { Metal Oxide }) & +\mathrm{Re}(\text { Reducing Agent }) \rightarrow \mathrm{Me}+ \\
& +\mathrm{ReO}+\mathrm{Q}
\end{aligned}
$$

Based on the above, Mg metal powder was chosen for the reduction of titanium oxide to titanium.

\subsection{Thermodynamic analysis}

Prior to these experiments, thermodynamic calculations for adiabatic combustion temperature $\left(T_{a d}\right)$ and equilibrium composition of the reaction products of the $\mathrm{TiO}_{2}+\alpha \mathrm{Mg}$ system were carried out using the FactSage software (Fig. 3).

$T_{a d}$ decreases as the $\mathrm{Mg}$ molar ratio increases, and the maximum value of $T_{a d}\left(1805^{\circ} \mathrm{C}\right)$ is expected at a stoichiometric point of $\alpha=2$, where the system consists of only $\mathrm{Ti}$ and $\mathrm{MgO}$ phases. Below this stoichiometric point, $T_{a d}$ decreases slightly due to evaporation of $\mathrm{Mg}$ as the reaction temperature increases; here the system is expected to be mainly composed of $\mathrm{Ti}$, $\mathrm{TiO}$ and $\mathrm{MgO}$. At $\alpha>2, T_{a d}$ continues to decrease due to excess $\mathrm{Mg}$, as the melting of excess $\mathrm{Mg}$ causes the reaction to become more endothermic. Here, the reaction products are $\mathrm{Ti}, \mathrm{MgO}$ and $\mathrm{Mg}$.

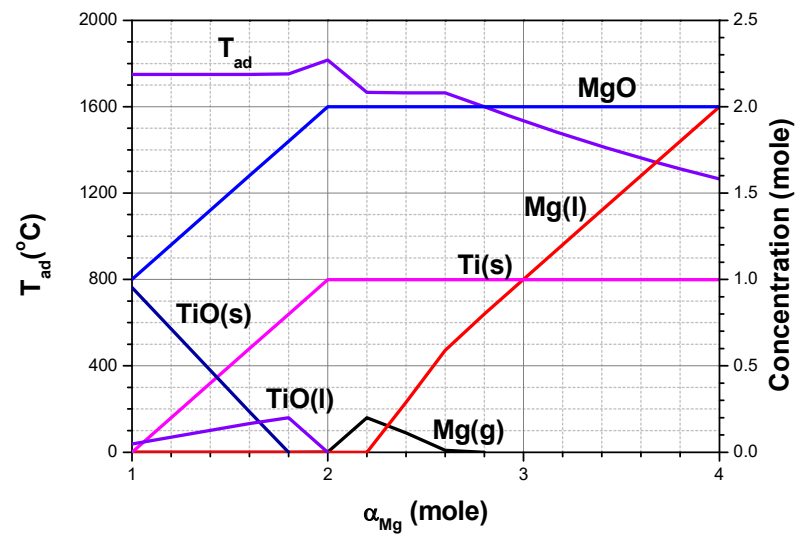

Fig. 3. Thermodynamic calculation of adiabatic combustion temperature and equilibrium phase concentration in the $\mathrm{TiO}_{2}+\alpha \mathrm{Mg}$ system

\subsection{Characteristics of combustion products}

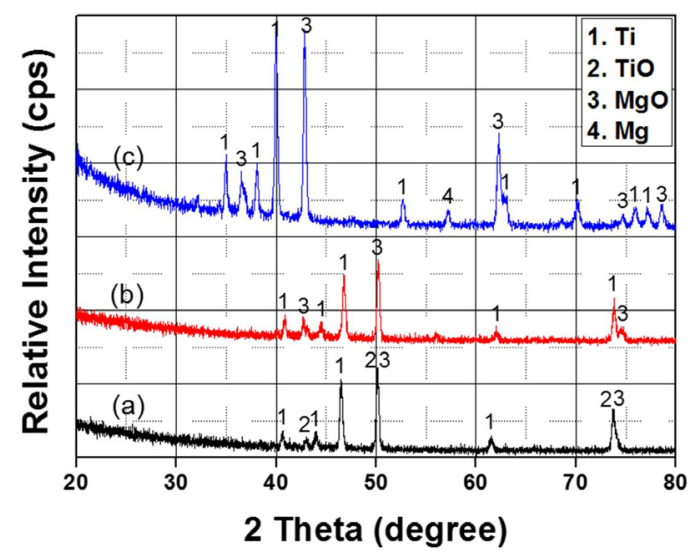

Fig. 4. XRD results of titanium powder: (a) $\alpha=2$, (b) $\alpha=3$, (c) $\alpha=4$, before leaching

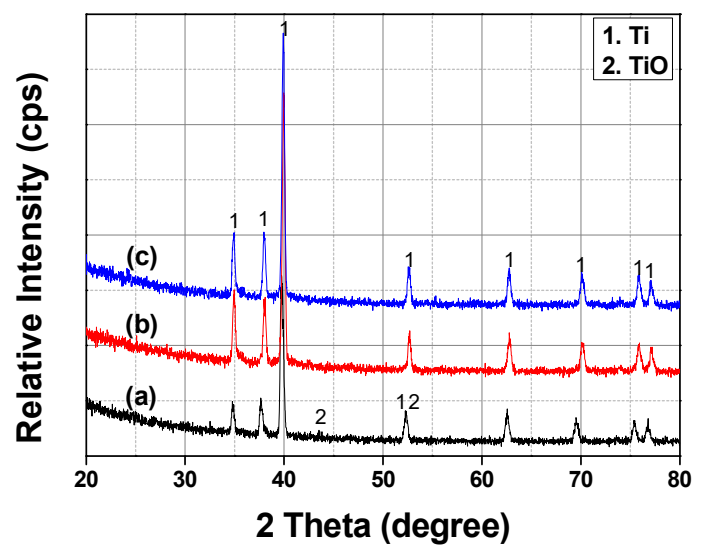

Fig. 5. XRD results of combustion products: (a) $\alpha=2$, (b) $\alpha=3$, (c) $\alpha=4$, after leaching

Fig. 4 and Fig. 5 show XRD results for the $\mathrm{TiO}_{2}+\alpha \mathrm{Mg}$ system $(2 \leq \alpha \leq 4)$ before and after acid leaching, respectively. Before leaching (Fig. 4a)), the combustion product consists of reduced $\mathrm{Ti}, \mathrm{MgO}$ and an intermediate $\mathrm{TiO}$ phase $(\alpha=2)$, where this $\mathrm{TiO}$ phase is present because of the high combustion temperature. At high reaction temperatures, $\mathrm{Mg}$ is melted and 
vaporized by the exothermic heat in the adiabatic chamber. At $\alpha=2, \mathrm{Mg}$ is not efficiently used for reduction which leads to intermediate oxides like $\mathrm{TiO}$ to be present in the system. This allows $\mathrm{Mg}$ vapor to leave the mixture, leading to an inefficient conversion of $\mathrm{TiO}_{2}$ into Ti. This effect can be minimized by adding excess $\mathrm{Mg}$ (Fig. 4b,c), which minimizes the TiO phase. However, at $\alpha=4$ (Fig. 4c)), unreacted $\mathrm{Mg}$ is also present. After leaching (Fig. 5), $\mathrm{MgO}$ and residual $\mathrm{Mg}$ were removed and $\mathrm{Ti}$ peaks are present for all conditions, indicating successful oxide reduction. However, a small amount of TiO is observed for $\alpha=2$.

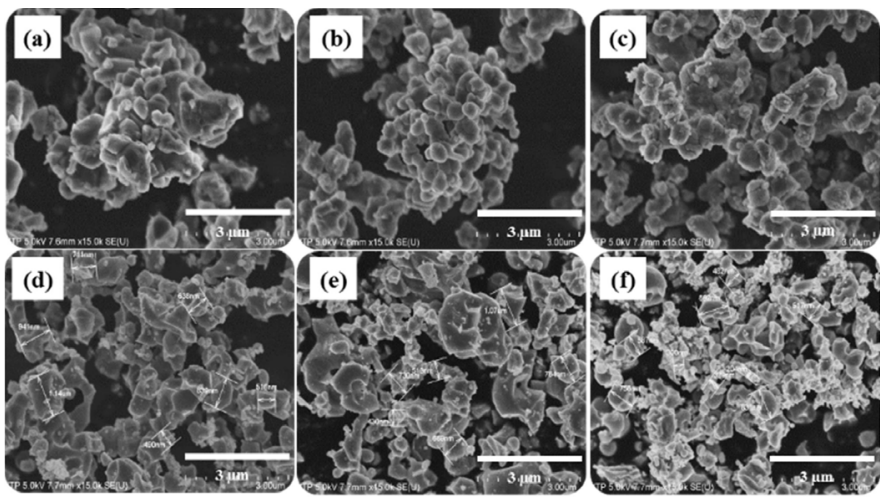

Fig. 6. FE-SEM images of the Ti powders: (a-c) before leaching, (d-f) after leaching

SEM analysis of the as-synthesized powder was also performed. Fig. 6 shows FE-SEM images of Ti particles before leaching (a-c) and after leaching (d-f), prepared at $\alpha=2,3$, and 4 . Before leaching, large agglomerated particles were present, whereas after leaching these particles became more dispersed. The overall size of the Ti particles clearly decreased as the molar ratio of $\mathrm{Mg}$ increased. As the $\mathrm{Mg}$ concentration increased, the combustion and reaction temperatures decreased, while the reaction time increased. This causes molten $\mathrm{Mg}$ to remain in contact with $\mathrm{TiO}_{2}$ for a longer period of time. As a result, an $\mathrm{MgO}$ layer is formed around the reduced Ti particle, which stops further grain growth and limits contact between adjacent Ti particles.

The oxygen concentration of the Ti powder was also measured, the results of which are shown in Fig. 7.

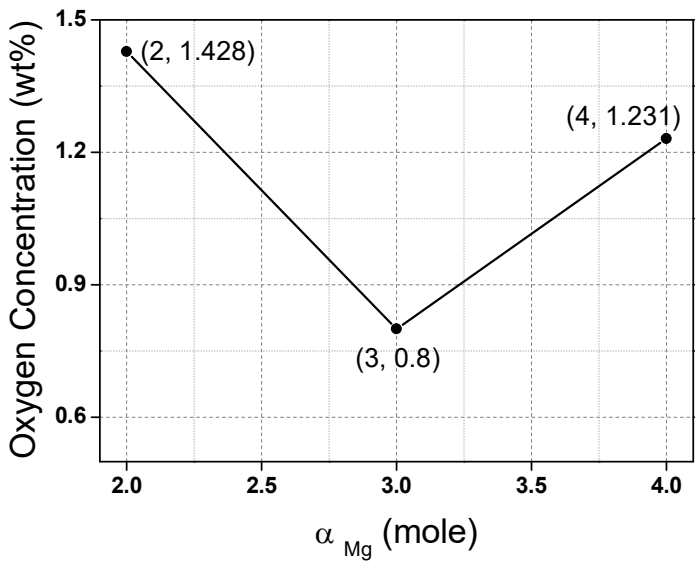

Fig. 7. Oxygen concentration of Ti powder obtained from the $\mathrm{TiO}_{2}+\alpha \mathrm{Mg}$ system
A lowest oxygen concentration of $0.8 \mathrm{wt} \%$ was present at $\alpha=3$, while the highest value $(1.428 \mathrm{wt} \%)$ occurred at $\alpha=2$ because of the incomplete reduction of $\mathrm{TiO}_{2}$.

\subsection{Combustion parameters}

Fig. 8 shows the effects of varying the $\mathrm{Mg}$ concentration on the combustion temperature $\left(T_{c}\right)$ and combustion wave propagation velocity $\left(U_{c}\right)$ of this system.

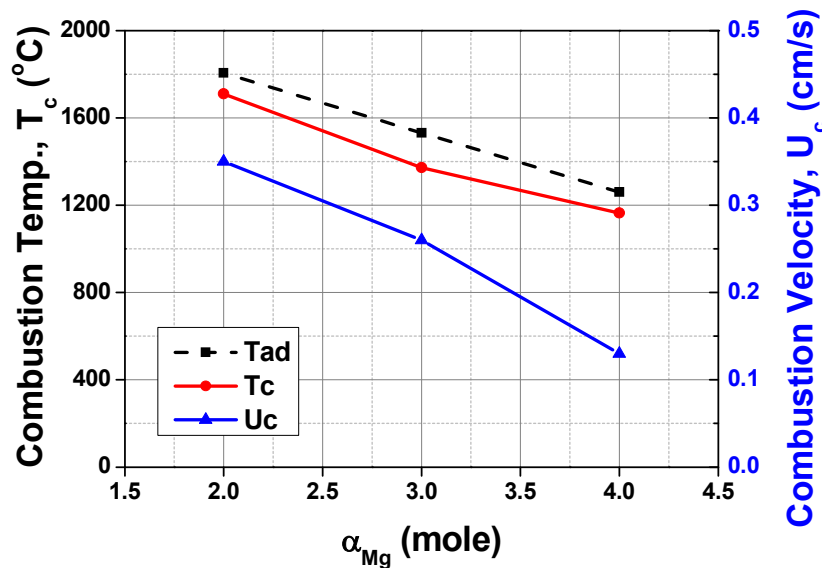

Fig. 8. Combustion parameters of the $\mathrm{TiO}_{2}+\alpha \mathrm{Mg}$ system

$T_{a d}$ and $T_{c}$ differ from each other because the reaction cannot be run under perfectly adiabatic conditions. As predicted by our thermodynamic calculations (Fig. 3), $T_{c}$ and $U_{c}$ decrease as the $\mathrm{Mg}$ concentration increases. The lowest values of $T_{c}\left(1164^{\circ} \mathrm{C}\right)$ and $U_{c}(0.13 \mathrm{~cm} / \mathrm{s})$ were calculated for $\alpha=4$, while the highest $T_{c}\left(1709^{\circ} \mathrm{C}\right)$ and $\mathrm{U}_{\mathrm{c}}(0.35 \mathrm{~cm} / \mathrm{s})$ were obtained at $\alpha=2$. This change in $U_{c}$ and $T_{c}$ can be explained by the changes in the thermal conductivity of combustion zone as the $\mathrm{Mg}$ concentration changes, as it greatly influences the density and size of the initial mixture. As mentioned in section $3.2, \alpha=3$ yields optimum oxygen conditions for the $\mathrm{TiO}_{2}+\alpha \mathrm{Mg}$ system $(2 \leq \alpha \leq 4)$.

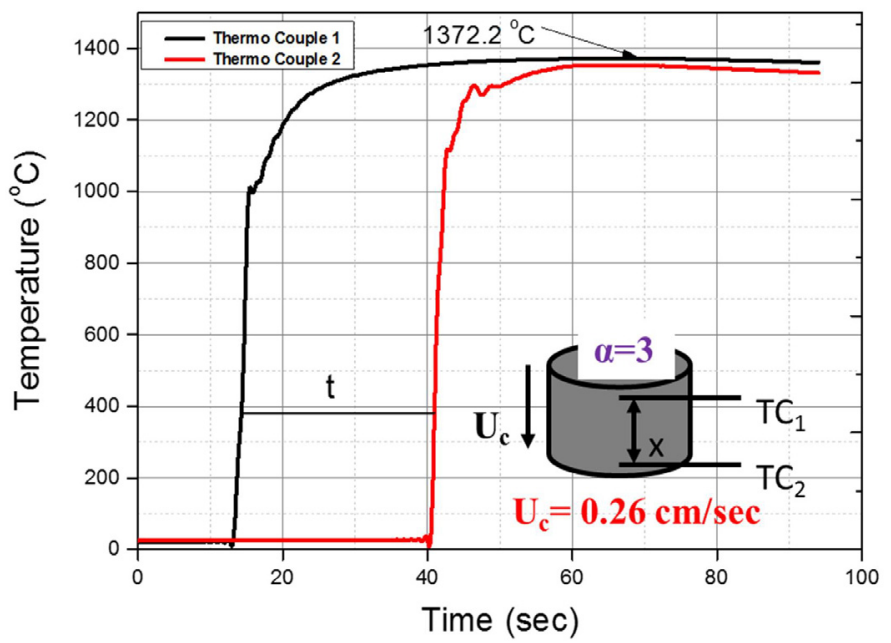

Fig. 9. Temperature-time profile recorded during the combustion of the $\mathrm{TiO}_{2}+\alpha \mathrm{Mg}$ system 
The time-temperature profile for the $\alpha=3$ system is shown in Fig. 9, where the obtained $T_{c}$ and $U_{c}$ values are $1372.2^{\circ} \mathrm{C}$ and $0.26 \mathrm{~cm} / \mathrm{s}$ respectively.

By utilizing changes in $U_{c}$ and $T_{c}$ based on changes to the $\mathrm{Mg}$ concentration, the activation energy of the $\mathrm{TiO}_{2}+\alpha \mathrm{Mg}$ system can be calculated using Eqs. 5-7.

$$
\begin{gathered}
U_{c}^{2}=A T_{c} \exp \left(-\frac{E}{R T_{c}}\right) \\
\ln \left(\frac{U c}{T_{c}}\right)=-\frac{E}{2 R T_{c}}+\ln A \\
\ln \left(\frac{U c}{T_{c}}\right)=-\frac{E}{2 R} \cdot \frac{1}{T_{c}}+\ln A
\end{gathered}
$$

As $\ln \left(U_{c} / T_{c}\right)$ depends linearly on $\left(1 / T_{c}\right)$ [20], Fig. 10 plots $\ln \left(U_{c} / T_{c}\right)$ and $\left(1 / T_{c}\right)$, indicating that the activation energy of the $\mathrm{TiO}_{2}+\alpha \mathrm{Mg}(2 \leq \alpha \leq 4)$ system is $20.5 \mathrm{~kJ} / \mathrm{mol}$.

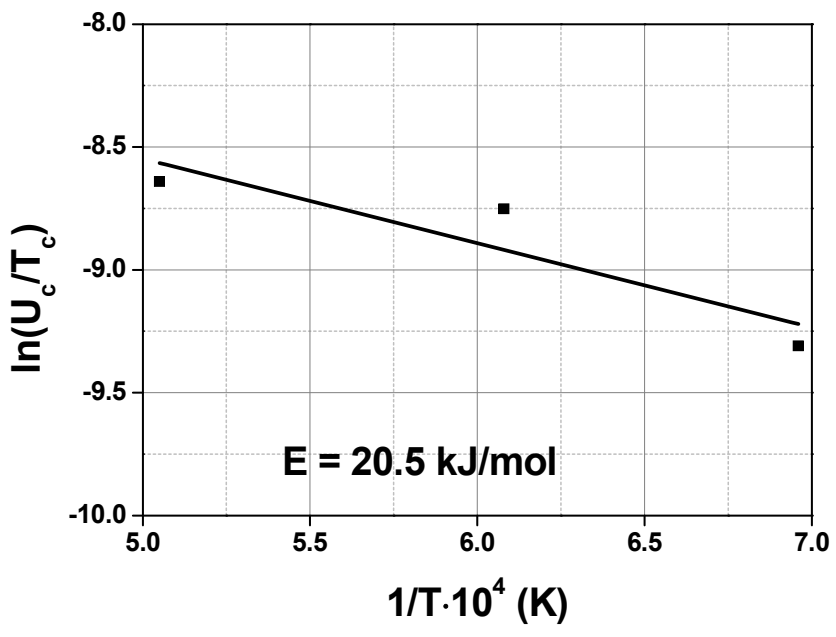

Fig. 10. Arrhenius plot $\left[\ln U_{c} / T_{c}\right.$ vs $\left.1 / T_{c}\right]$ for the combustion of the $\mathrm{TiO}_{2}+\alpha \mathrm{Mg}$ system

This value is low because $\mathrm{Mg}$ is in liquid state before the reaction, while $\mathrm{TiO}_{2}$ is still solid. The liquid $\mathrm{Mg}$ begins to diffuse into the solid $\mathrm{TiO}_{2}$ phase, which lowers the activation energy required to carry out the reaction. Combustion parameters for the reaction mixture are summarized in Table 2 .

\begin{tabular}{|c|c|c|c|c|c|}
\hline $\begin{array}{c}\text { Mg con- } \\
\text { centration } \\
\text { (mole) }\end{array}$ & $\begin{array}{c}\text { Adiabatic } \\
\text { Temp. } \\
\left(T_{a d}\right)\end{array}$ & $\begin{array}{c}\text { Com- } \\
\text { bustion } \\
\text { Temp. }\left(T_{c}\right)\end{array}$ & $\begin{array}{l}\text { Combu- } \\
\text { stion Velo- } \\
\text { city }\left(U_{c}\right)\end{array}$ & $\begin{array}{l}\text { Green } \\
\text { Density }\end{array}$ & $\begin{array}{c}\text { Acti- } \\
\text { vation } \\
\text { energy }\end{array}$ \\
\hline 2 & 1815.53 & 1709 & $\begin{array}{c}0.35 \\
\mathrm{~cm} / \mathrm{sec}\end{array}$ & $\begin{array}{l}0.935 \\
\mathrm{~g} / \mathrm{cm}^{3}\end{array}$ & \multirow{3}{*}{$\begin{array}{c}20.5 \\
\mathrm{~kJ} / \mathrm{mol}\end{array}$} \\
\hline 3 & 1534.27 & 1372.2 & $\begin{array}{c}0.26 \\
\mathrm{~cm} / \mathrm{sec}\end{array}$ & $\begin{array}{l}1.324 \\
\mathrm{~g} / \mathrm{cm}^{3}\end{array}$ & \\
\hline 4 & 1264.8 & 1164 & $\begin{array}{c}0.13 \\
\mathrm{~cm} / \mathrm{sec}\end{array}$ & $\begin{array}{l}1.376 \\
\mathrm{~g} / \mathrm{cm}^{3}\end{array}$ & \\
\hline
\end{tabular}

TABLE 2

Combustion parameters of the $\mathrm{TiO}_{2}+\alpha \mathrm{Mg}$ system

\subsection{Plasma Treatment}

As shown in Fig. 6, the CS process tends to yield irregular particle shapes, while spherical particles are more desirable for metal 3D printing. Spheroidization was carried out on the as-synthesized Ti powder using DC plasma treatment, which is a sophisticated technique for controlling powder purity and size. Fig. 11 shows Ti powder morphology and size distributions before and after plasma treatment. After spheroidization, the $\mathrm{Ti}$ powder morphology was successfully changed from an irregular shape to a spherical one. Furthermore, the particle size increased $(4.7 \mu \mathrm{m} \rightarrow 31.8 \mu \mathrm{m})$ due to particle coarsening. The particle size distribution was also decreased after treatment.

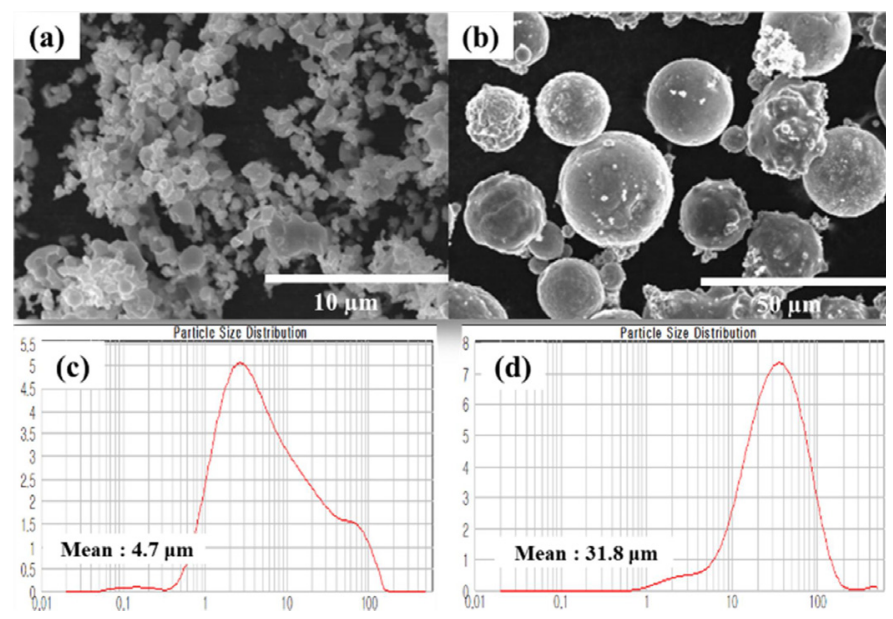

Fig. 11. FE-SEM morphology and size distribution of the Ti powders: $(a, c)$ before and $(b, d)$ after DC plasma treatment

\section{Conclusions}

In this study, single phase Ti powder was successfully fabricated by CS, and spheroidization of the resulting Ti powder was performed. Throughout the process, the possibility of obtaining Ti powder for use as raw materials for 3D printing was investigated. For the $\mathrm{TiO}_{2}+\alpha \mathrm{Mg}$ system studied here, a stoichiometric point of $\alpha=2$ led to the highest value of $T_{c}\left(1709^{\circ} \mathrm{C}\right)$, and $\mathrm{TiO}$ was still present due to incomplete reduction. $\mathrm{Mg}$ was melted and vaporized by high exothermic heat from the reduction of titanium oxide therefore 2 mole of $\mathrm{Mg}$ does not perfectly used. The combustion temperature and combustion wave propagation velocity gradually decreased with increasing $\mathrm{Mg}$ concentration, and $\mathrm{Ti}$ oxide powder was successfully reduced at higher $\mathrm{Mg}$ concentrations. Therefore, $\alpha=3$ was chosen as the optimum conditions for the $\mathrm{TiO}_{2}+\alpha \mathrm{Mg}$ system, with $T_{c}$ and $U_{c}$ values of $1372^{\circ} \mathrm{C}$ and $0.26 \mathrm{~cm} / \mathrm{s}$ respectively. Furthermore, this ratio also had the lowest oxygen concentration in this study ( $0.8 \mathrm{wt} \%)$. The activation energy of the $\mathrm{TiO}_{2}+\alpha \mathrm{Mg}$ system was calculated as $20.5 \mathrm{~kJ} / \mathrm{mol}$ (using $T_{c}$ and $U_{c}$ ). In this system, a high activation energy was not required because liquid $\mathrm{Mg}$ diffuses into the solid $\mathrm{TiO}_{2}$ phase prior to reaction. Spheroidization of the as-synthesized Ti powder was carried out using DC plasma treat- 
1062

ment, which formed spherical particles with size that increased from $4.7 \mu \mathrm{m}$ to $31.8 \mu \mathrm{m}$, which are more than adequate for $3 \mathrm{D}$ metal printing processes.

\section{Acknowledgments}

This research was supported by an internal R\&D program of the Korea Institute of Industrial Technology (KITECH), funded by the Ministry of Strategy and Finance, Korea and partially supported by the technology innovation program, 10063427, Development of eco-friendly smelting technology for the production of rare metal production for lowering manufacturing costs using solid oxide membrane funded by the Ministry of Trade, Industry \&Energy

\section{REFERENCES}

[1] M. Ribeiro, M. Moreira, J. Ferreira, J. Mater. Proc. Tech. 143, 458 (2003).

[2] M. Rahman, Z. Wang, Y. Wong, JSME Int. J. Series C 49, 11 (2006).

[3] K.H. Kramer, in: P. Lacombe, R. Tricot, G. Beranger (Eds.), Proceedings of the 6th World Conference on Titanium, Cannes, 521 (1988)

[4] Y.M. Kim, Y.B. Song, S.H. Lee, Y.S. Kwon, J. Kor. Powd. Met. Inst. 21, 4 (2014).

[5] K.F. Leong, C.M. Cheah, C.K. Chua, Biomater. 24, 2363 (2003).
[6] S.J. Kalita, S. Bose, H.L. Hosick, A. Bandyopadhyay, Mater. Sci. Eng. C. 23, 611 (2003)

[7] A. Woesz, M. Rumpler, J. Stampfl, F. Varga, N. Fratzl-Zelman, P. Roschger, K. Klaushofer, P. Fratzl, Mater. Sci. Eng. C. 25, 181 (2005).

[8] T. Boland, A. Ovsianikov, B.N. Chickov, A. Doraiswamy, R.J. Narayan, W.Y. Yeong, K.F. Leong, C.K. Chua, Adv. Mater. Process. 165, 51 (2007).

[9] O.L.A. Harrysson, O. Cansizoglu, D.J. Marcellin-Little, D.R. Cormier, H.A. West II, Mater. Sci. Eng. C. 28, 366 (2008).

[10] W.J. Kroll, Trans. Electrochem. Soc. 78, 35 (1940).

[11] J. Dawes, R. Bowerman, R. Trepleton, Johnson Matthey Technol. Rev. 59, 243 (2015).

[12] F.H. Froes, M.N. Gungor, M. Ashraf Imam, JOM 28 (2007).

[13] H.H. Nersisyan, H.I. Won, C.W. Won, J.H. Kim, J. Chem. Eng. 235, 67 (2014).

[14] J. Gambogi, S.J. Gerdemann, DOE/ARC (1999).

[15] D.J. Fray, G.Z. Chen, T.W. Farthing, Nature 407 (6802), 361 (2000).

[16] R.O. Suzuki, K. Ono, TMS Yazawa International Symposium (2003).

[17] A.G. Merzhanov, J. Mat. Proc. Tech. 56, 222 (1996).

[18] J.J. Moore, H.J. Feng, Prog. Mater. Sci. 39, 275 (1995).

[19] H.H. Nersisyan, J.H. Lee, C.W. Won, Mater. Res. Bull. 38, 1135 (2003).

[20] T.S. Azatyan, V.M. Maltsev, A.G. Merzhanov, V.A. Seieznev, Com. Explos. Shock Waves, 15, 35 (1979). 